Bidang ilmu: Teknik Elektromedik

\title{
PENGEMBANGAN PLATFORM ONLINE SIMULASI VIRTUAL PENGUJIAN DAN KALIBRASI VENTILATOR BERBASIS BROWSER
}

Tata Yunita Ovtaria1), Apriliani1), Indah Rahma Dhona2), Rino Ferdian Surakusumah')

Program Studi Teknologi Rekayasa Elektro-medis ${ }^{1)}$,

Program Studi Kesehatan Masyarakat ${ }^{2}$

STIKes Al Insyirah Pekanbaru

tatayunita082@gmail.com¹), aprilianiharahap04@gmail.com²), indahrahmadhona@gmail.com³), rinofs@stikes-alinsyirah.ac.d ${ }^{4}$

\begin{abstract}
ABSTRAK
Ventilator merupakan alat kesehatan yang paling dibutuhkan di masa pandemi ini. Berbagai institusi telah berusaha mengembangkan ventilator, akan tetapi banyak yang terkendala dengan hasil pengujian dan kalibrasinya yang tidak sesuai. Hal ini dikarenakan ketidaktahuan terhadap metode pengujian dan kalibrasi ventilator yang sesuai standar. Oleh karena itu, dikembangkanlah platform Platform Online Simulasi Virtual Pengujian dan Kalibrasi Ventilator Berbasis Browser. Platform ini kedepannya akan digunakan oleh institusi pengembang ventilator untuk melakukan pembelajaran dan meningkatkan kompetensi melalui pelatihan terkait pengujian dan kalibrasi ventilator. Penelitian ini dibatasi dengan menggunakan beberapa ruang lingkup pengujian yaitu tidal volume, minute volume, breath rate, I:E ratio, PEEP, inspiration time, dan Expiration time. Tahapan metode penelitian yang akan dilakukan mulai dari studi literatur, produk, library, algoritma, pengumpulan data ventilator dan gas flow analyzer, dilanjutkan dengan desain sistem, antarmuka pengguna, dan elemen visual, kemudian dilakukan pengembangan sistem dan antarmuka pengguna, lalu dilakukan pengujian fungsi, dan pengalaman pengguna. Hasil pengujian menunjukan seluruh fungsi $100 \%$ terlaksana dengan baik dan pengalaman pengguna 38\% menunjukkan setuju dengan kriteria pengalaman pengguna yang terdiri dari Daya Tarik, Efisiensi, Perspicuity, Ketergantungan, Stimulasi, Novelty, Kepercayaan, Estetika, Adaptabilitas, Kegunaan, Penggunaan Intuitif, Nilai, Konten yang Dapat Dipercaya, Kualitas Isi, Haptics, dan Akustik.
\end{abstract}

Kata kunci: Ventilator, Pengujian dan Kalibrasi, Platform Virtual

\section{ABSTRACT}

Ventilators are the most needed medical equipment during this pandemic. Various institutions have tried to develop ventilators, but many of them were constrained by inappropriate test and calibration results. This was due to ignorance of the standard ventilator testing and calibration method. Therefore, the BrowserBased Ventilator Testing and Calibration Virtual Simulation Online Platform was developed. In the future, this platform will be used by ventilator development institutions to learn and improve competence through training related to ventilator testing and calibration. This study was limited by using several scopes of testing, namely tidal volume, minute volume, breath rate, I:E ratio, PEEP, inspiration time, and expiration time. The stages of the research method that were carried out starting from the study of literature, products, libraries, algorithms, collecting data on ventilators and gas flow analyzers, followed by system design, user interfaces, and visual elements, then developing systems and user interfaces, then testing functions, and user experience. The test results showed that all functions was 100\% well implemented and user experience 38\% agrees with the user experience criteria consisting of Attractiveness, Efficiency, Perspicuity, Dependence, Stimulation, Novelty, Trust, Aesthetics, Adaptability, Usability, Intuitive Use, Values, Trustworthy Content, Quality Content, Haptics and Acoustics. 
Keywords: Ventilator; Testing and Calibration, Virtual Platform

Alamat korespondensi: STIKes Al Insyirah Pekanbaru, Jalan Parit Indah No.38 Pekanbaru Riau

Email: tatayunita082@gmail.com

Nomor Hp: +62 852-1128-5502

\section{PENDAHULUAN}

Ventilator merupakan alat bantu pernapasan bertekanan positif atau negatif yang menghasilkan aliran udara terkontrol pada jalan napas pasien sehingga mampu mempertahankan ventilasi oleh pemberian oksigen dalam jangka waktu lama. Ventilator berperan penting pada era COVID-19 pada pasien yang mengalami kelelahan atau kegagalan nafas sebagai alat bantu nafas. Berdasarkan keterangan dari Irwandy (2020), sekitar 60\% (5.171) pasien di ruang ICU membutuhkan ventilator sedangkan ketersediaan ventilator masih sangat terbatas. Semenjak COVID-19 menyebar di Indonesia, para peneliti berusaha untuk mengembangkan ventilator sederhana untuk mendukung percepatan pengadaan teknologi kesehatan di masa pandemi. Berdasarkan hasil diskusi dengan Balai Pengamanan Fasilitas Kesehatan (BPFK) Jakarta tanggal 11 Februari 2021, sebenarnya banyak institusi yang memproduksi ventilator akan tetapi sebagian besar terkendala di proses pengujian dan kalibrasinya dikarenakan belum banyak yang mengetahui parameter-parameter apa yang diujikan. Hal ini dikarenakan pengujian dan kalibrasi alat kesehatan merupakan kompetensi yang saat ini belum banyak dikuasai di Indonesia. Oleh karena itu, diperlukan suatu media yang dapat mendukung peningkatan kompetensi pengujian dan kalibrasi ventilator sehingga mempercepat pengadaan ventilator yang akan diproduksi oleh peneliti dan institusi di Indonesia

Disisi lain, COVID-19 juga memicu evolusi di bidang pendidikan dan pelatihan khususnya di bidang kesehatan. Salah satu teknologi yang perlu dikembangkan secara cepat adalah simulasi menggunakan Extended Reality (ER) (Pears et al., 2020). Perkembangan teknologi imersif dalam bentuk Extended Reality (ER) yang terdiri dari Virtual Reality (VR), Augmented Reality (AR), and Mixed Reality (MR) memulai era baru dalam dunia pendidikan dan pelatihan (Doolani et al., 2020). Banyak software simulasi pelatihan kompetensi kesehatan yang telah diteliti dan dikembangkan menggunakan teknologi ER. Mulai dari penggunaan video simulasi sampai kepada software interaktif secara virtual (Kolesnyk, 2020). Akan tetapi, berdasarkan hasil pencarian di mesin pencari, belum ada platform yang khusus melakukan simulasi pengujian dan kalibrasi alat kesehatan terlebih lagi secara virtual.

Untuk mengatasi permasalahan di atas, perlu dikembangkan sebuah platform perangkat lunak berbasis browser yang berfungsi menampilkan simulasi virtual proses pengujian dan kalibrasi ventilator. Platform ini bernama Virtual Testing and Calibration Ventilator (V-TCV). Platform ini memiliki tampilan interaktif yang terdiri dari model 2D ventilator dan alat uji dan kalibrasinya yaitu Electrical Safety Analyzer dan Gas Flow Analyzer beserta aksesoris yang dibutuhkan. Platform memiliki halaman kerja dimana pengguna dapat meletakkan ventilator dan alat uji dan kalibratornya kemudian menghubungkan seluruh alat tersebut sesuai dengan metode kerja pengujian dan kalibrasi alat kesehatan yang dikeluarkan oleh Kementerian Kesehatan Republik Indonesia (2018). Pengguna dapat menjalankan simulasi sehingga didapatkan data hasil pengujian dan kalibrasi ventilator kemudian melakukan analisis laporan dan analisis ketidakpastian sampai dikeluarkannya sertifikat pengujian dan kalibrasi ventilator. Platform ini kedepannya dapat digunakan oleh mahasiswa, peneliti, praktisi di perguruan tinggi, industri, ataupun lembaga pengujian dan kalibrasi alat kesehatan untuk melakukan pembelajaran dan meningkatkan kompetensi pengujian dan kalibrasi ventilator. 


\section{METODE PENELITIAN}

\section{Perancangan atau Penyusunan Desain Produk}

Dalam tahap ini sudah ditentukan acuan yang akan digunakan dan dikembangkan, merancang konsep dan ide baru atau memodifikasi konsep dan ide yang sudah ada, terdapat beberapa tahap yang harus dilakukan sebelum hasil dari rancangan dijadikan aplikasi yang terdiri dari tahap pengumpulan data, desain serta pengembangan sistem.

Pengumpulan Data Alat Kesehatan, Kalibrator, dan Metode Kerja

Alat kesehatan dan kalibrator yang akan dikembangkan simulasi pengujian dan kalibrasinya adalah ventilator, electrical safety analyzer, dan gas flow analyzer. Informasi parameter fungsi dari masing-masing alat yang akan dikumpulkan dan akan menjadi variabel dalam platform. Informasi ini didapatkan dari metode kerja pengujian dan kalibrasi masing-masing alat yang dikeluarkan oleh kementerian kesehatan dan juga dari user manual masing-masing alat. Data visual juga akan dikumpulkan sebagai referensi untuk membuat desain komponen visual. Desain Komponen Visual, Antarmuka, Kerangka Sistem, Sistem Manajemen Data dan Protokol Komunikasi.

Platform ini diharapkan dapat memberikan kenyamanan dan informatif kepada pengguna sehingga tampilan komponen pada platform seperti alat kesehatan dan alat kalibrasi harus didesain sesuai dengan alat aslinya dengan visual digital yang menarik. Visual komponen didesain menggunakan software desain berbentuk vektor.

\section{Desain Platform}

Desain antarmuka terdiri dari antarmuka pengelola dan antarmuka pengguna. Desain terdiri dari menu, jendela, layer, toolbar, overflow icon, working area, element bar, dll. Kerangka sistem terdiri dari input, process, dan output. Desain sistem manajemen data dilakukan dengan melihat alur perpindahan data dari input, proses, dan output. Desain protokol komunikasi dilakukan dengan melihat hubungan antar user dan privilege yang ada serta perpindahan data. Pengembangan Sistem, Antarmuka Pengelola dan Pengguna serta Pengisian database

\section{Pengembangan Platform}

Antarmuka pengelola dikembangkan menggunakan teknologi WebGL dan sistem dikembangkan menggunakan Visual Code Studio. Setelah antarmuka pengelola dan sistem telah selesai dikembangkan, seluruh database alat kesehatan dan alat kalibrasi yang telah dikumpulkan akan diinput ke dalam sistem untuk dilakukan pengujian sistem.

Sebagai suatu platform simulasi, diharapkan sistem yang dikembangkan dapat memperlihatkan hasil pengujian dan kalibrasi yang beragam. Oleh karena itu, dikembangkanlah sistem Precision Rate (PR) dan Accuracy Rate (AR). Precision Rate (PR) adalah tingkat presisi dari Nilai Penunjukan (NP) terhadap Nilai Setting (NS). Jika precision ratenya rendah, maka NS akan semakin tidak pasti atau bervariasi terhadap Nilai Setting (NS). Accuracy Rate (AR) adalah tingkat ketepatan Nilai Penunjukan (NP) terhadap Nilai Setting (NS). Semakin kecil accuracy rate, maka NP akan semakin jauh dari nilai NS. Precision Randomize Factor (PRF) adalah nilai pengali terhadap nilai setting sehingga menghasilkan nilai penunjukan yang tersebar sesuai nilai Precision Rate (PR) Nilai Setting (NS) adalah nilai yang diatur pada ventilator sedangkan Nilai Penunjukan (NP) adalah nilai yang terukur dan dilihat pada ventilator maupun pada gas flow analyzer. Formulasi yang dikembangkan menggunakan fungsi randbetween yang akan menghasilkan nilai random dari 2 buah lingkup nilai. Nilai PRF dan NP dikalkulasikan melalui formulasi di bawah ini:

$$
\mathrm{PRF}=1+(2 * \text { RANDBETWEEN }(0 ;(100-\mathrm{PR}) * 10) / 10-(100-\mathrm{PR}) / 100
$$

$$
\mathrm{NP}=\mathrm{NS} * \mathrm{PRF}+\mathrm{NS} *(100-\mathrm{AR}) / 100
$$

\section{Hasil Pengujian Alat atau Produk}

Pengujian fungsi platform dilakukan dengan melihat keberhasilan fitur-fitur yang terdapat dalam platform seperti fitur pendaftaran startup, user (sign up), sing in, pembukaan jendela utama yang akan menampilkan toolbar, working area, elemen bar, peletakan elemen ke working area, pengaturan parameter elemen, pengkoneksian antar elemen, rubbing simulation, penampilan output, 
dll. Setelah pengujian fungsi dilaksanakan, platform akan digunakan oleh beberapa pengguna dengan parameter Daya Tarik, Efisiensi, Perspicuity, Ketergantungan, Stimulasi, Novelty, Kepercayaan, Estetika, Adaptabilitas, Kegunaan, Penggunaan Intuitif, Nilai, Konten yang Dapat Dipercaya, Kualitas Isi, Haptics, dan Akustik.

\section{HASIL DAN PEMBAHASAN}

Hasil Pengumpulan dan ekstraksi data Input Output Ventilator dan Gas Flow Analyzer

\begin{tabular}{|c|c|c|c|c|}
\hline Input (In) & Output (Out) & Process (P) & Indicator (I) & Monitor (M) \\
\hline $\begin{array}{l}\text { Air and O2 } \\
\text { supply }\end{array}$ & inspiratory outlet & fixed keys & patient category & $\begin{array}{c}\text { Informative text messages, } \\
\text { which include a purple } \\
\text { symbol when triggered by } \\
\text { the patient }\end{array}$ \\
\hline Power cable & Patient system & rotary dials & $\begin{array}{c}\text { AC Power } \\
\text { indicator (green) }\end{array}$ & Alarm messages \\
\hline Expiratory inlet & Loudspeaker & $\begin{array}{c}\text { module } \\
\text { compartment }\end{array}$ & $\begin{array}{l}\text { Standby } \\
\text { indicator } \\
\text { (yellow) }\end{array}$ & $\begin{array}{l}\text { Waveform area - for } \\
\text { monitoring two to four } \\
\text { individually scaled } \\
\text { parameters, including a } \\
\text { pressure/flow loop }\end{array}$ \\
\hline $\begin{array}{l}\text { Servo guard, } \\
\text { viral/bacterial } \\
\text { filter }\end{array}$ & $\begin{array}{l}\text { Alarm output } \\
\text { connection } \\
\text { option }\end{array}$ & $\begin{array}{l}\text { Active mode of } \\
\text { ventilation }\end{array}$ & $\begin{array}{l}\text { Luminescence } \\
\text { detector - for } \\
\text { automatically } \\
\text { adjusting screen } \\
\text { brightness }\end{array}$ & $\begin{array}{c}\text { Measured values and alarm } \\
\text { limits display } \\
\text { (customizable) }\end{array}$ \\
\hline $\begin{array}{c}\text { Slot for } \\
\text { Ventilation } \\
\text { Record Card }\end{array}$ & Expiratory outlet & $\begin{array}{c}\text { Auto Mode } \\
\text { On/Off }\end{array}$ & $\begin{array}{l}\text { Additional } \\
\text { settings }\end{array}$ & \\
\hline $\begin{array}{c}\text { Cable reel for the } \\
\text { control cable }\end{array}$ & Inspiratory outlet & \begin{tabular}{|c|} 
Admit \\
patient/Entered \\
patient data and \\
admission date \\
\end{tabular} & $\begin{array}{c}\text { Additional } \\
\text { measured values }\end{array}$ & \\
\hline $\begin{array}{c}\text { Control cable (2.9 } \\
\text { meters long) }\end{array}$ & & $\begin{array}{c}\text { Nebulizer } \\
\text { On/Off }\end{array}$ & Air / Luft & \\
\hline Gas inlet for air & & $\begin{array}{c}\text { System status } \\
\text { parameters }\end{array}$ & $\mathrm{O} 2$ & \\
\hline Gas inlet for $\mathrm{O} 2$ & & \begin{tabular}{|} 
Main Rotary \\
Dial-used to \\
select a menu \\
touch pad or \\
parameter box, to \\
adjust values, \\
and to confirm \\
settings
\end{tabular} & Model number & \\
\hline \begin{tabular}{|c|} 
AC power \\
supply connector
\end{tabular} & & $\begin{array}{l}\text { special Function } \\
\text { Keys-used to }\end{array}$ & Serial number & \\
\hline
\end{tabular}




\begin{tabular}{|c|c|c|c|}
\hline with fuse & $\begin{array}{c}\text { start special } \\
\text { ventilatory } \\
\text { functions }\end{array}$ & & \\
\hline $\begin{array}{c}\text { External }+12 \mathrm{~V} \\
\text { DC inlet }\end{array}$ & $\begin{array}{c}\text { Direct Access } \\
\text { Knobs - used for } \\
\text { immediate } \\
\text { adjustment of } \\
\text { breathing } \\
\text { parameters }\end{array}$ & $\begin{array}{l}\text { Manufacturing } \\
\text { information }\end{array}$ & \\
\hline $\begin{array}{l}\text { Optional } \\
\text { connector }\end{array}$ & $\begin{array}{c}\text { Start/Stop } \\
\text { (Standby) } \\
\text { ventilation key }\end{array}$ & $\begin{array}{c}\text { Equipotentiality } \\
\text { terminal, label }\end{array}$ & \\
\hline $\begin{array}{l}\text { User interface } \\
\text { connector }\end{array}$ & $\begin{array}{l}\text { On/Off switch } \\
\text { (rear side) }\end{array}$ & $\begin{array}{c}\text { Fuse label T } \\
2.5 \mathrm{AL}\end{array}$ & \\
\hline RS232 connector & $\begin{array}{c}\text { Service } \\
\text { connector }\end{array}$ & $\begin{array}{c}\text { AC power } \\
\text { supply voltage }\end{array}$ & \\
\hline Expiratory inlet & $\begin{array}{l}\text { On/Off switch } \\
\text { (Set to On; when } \\
\text { off, battery } \\
\text { continues to } \\
\text { charge) }\end{array}$ & Battery lock & \\
\hline
\end{tabular}

\section{Hasil Pengembangan Website Platform}

Hasil pengembangan website platform dapat dilihat pada Gambar 1 sampai Gambar 7.

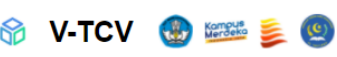

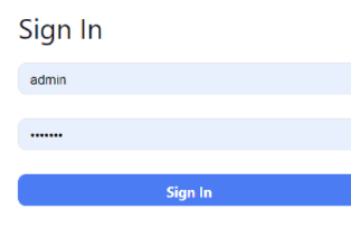




\section{Gambar 1. Halaman Sign In}

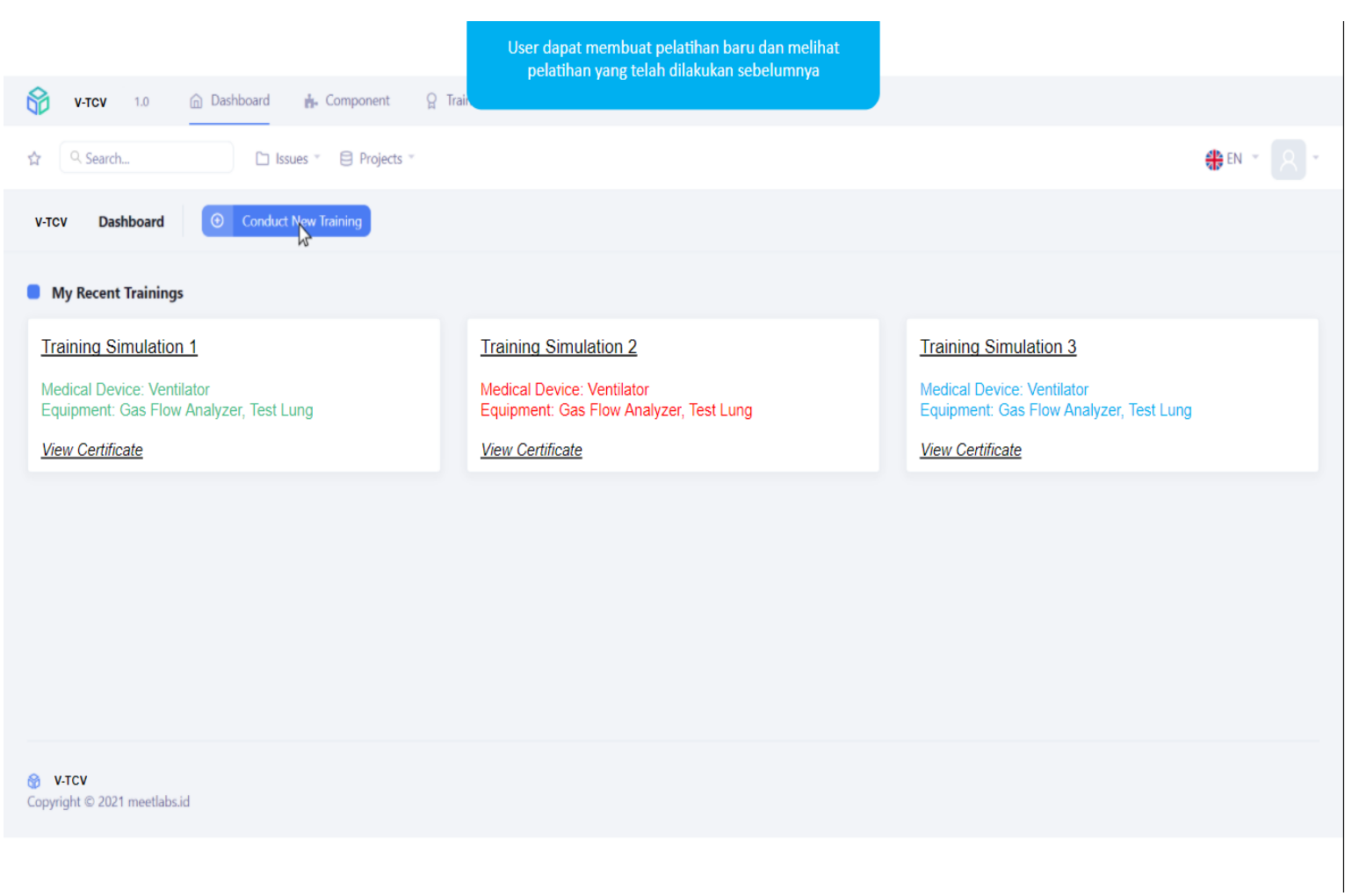

Gambar 2. Halaman Dashboard Pengguna

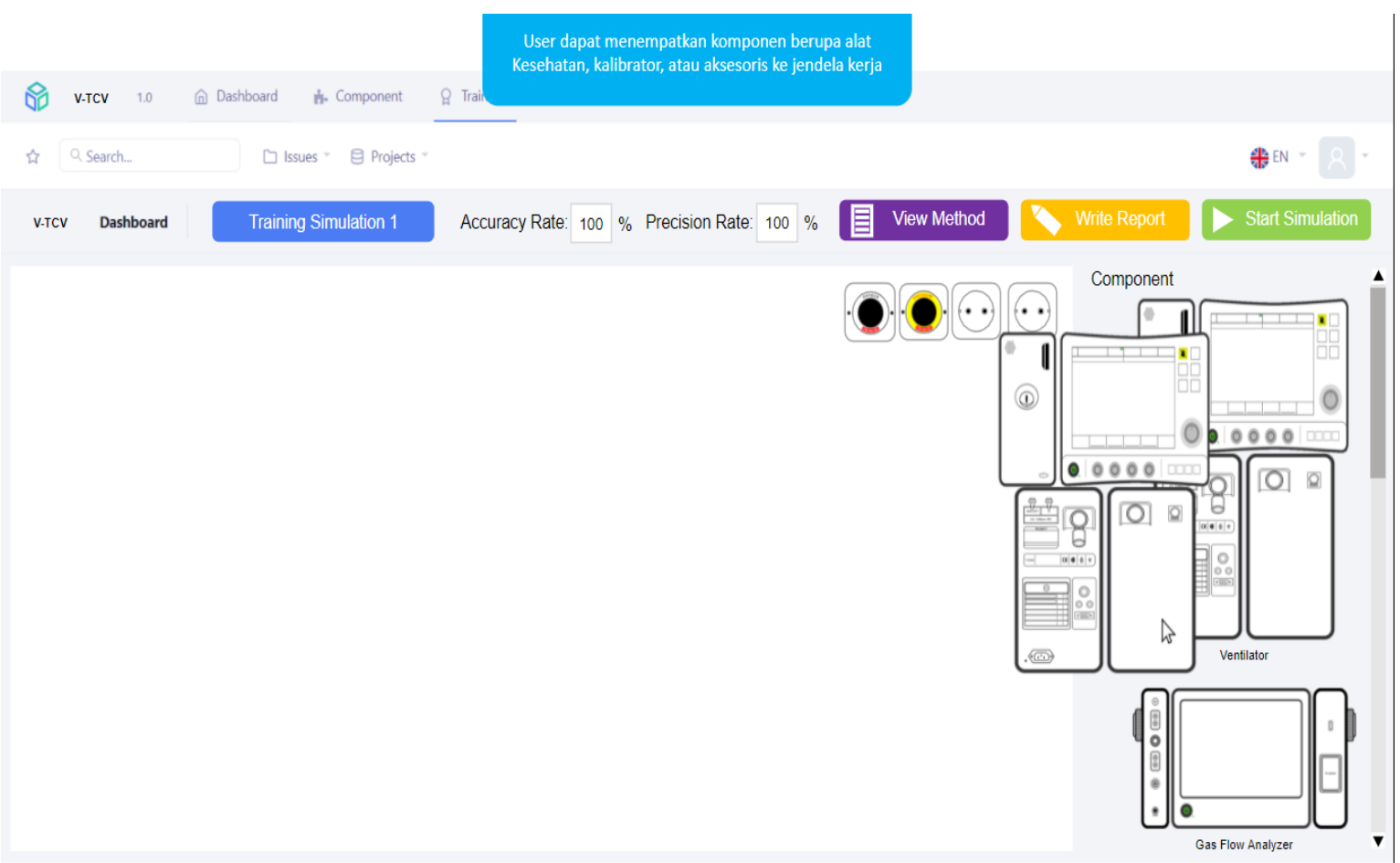




\section{Gambar 3. Halaman Kerja Pelatihan dan Peletakan Komponen}

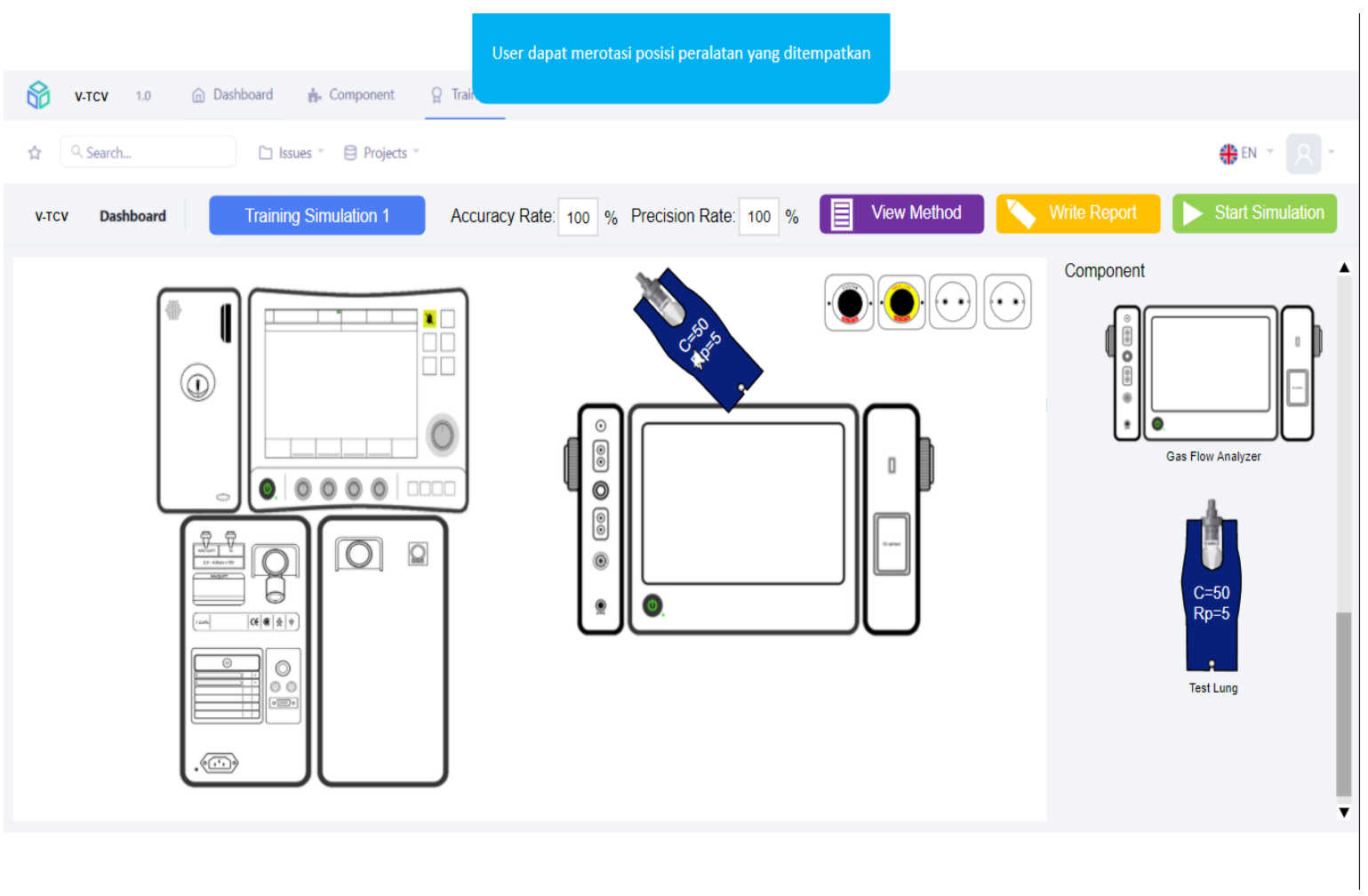

Gambar 4. Rotasi Komponen

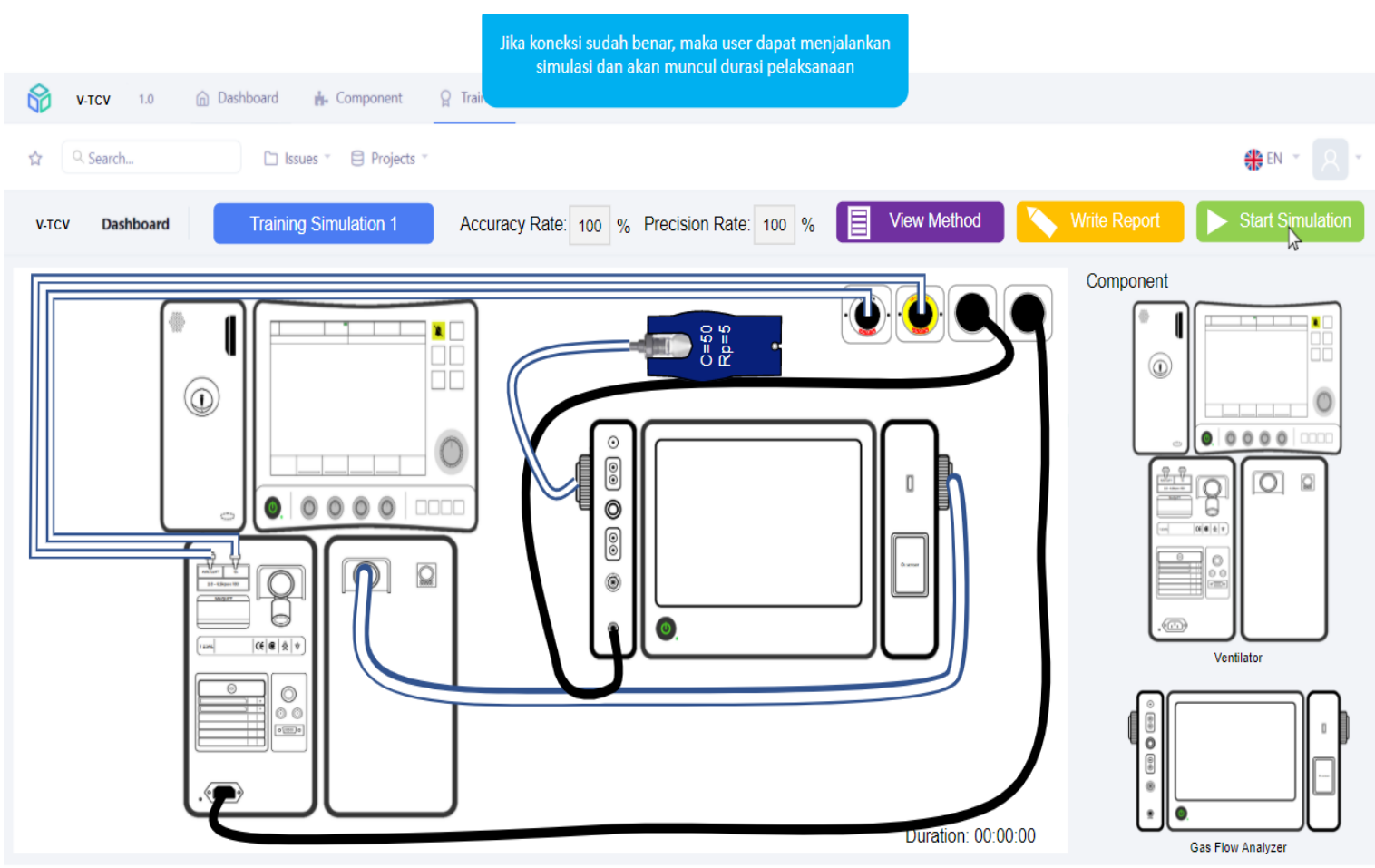


Gambar 5. Menghubungkan komponen sesuai metode kerja

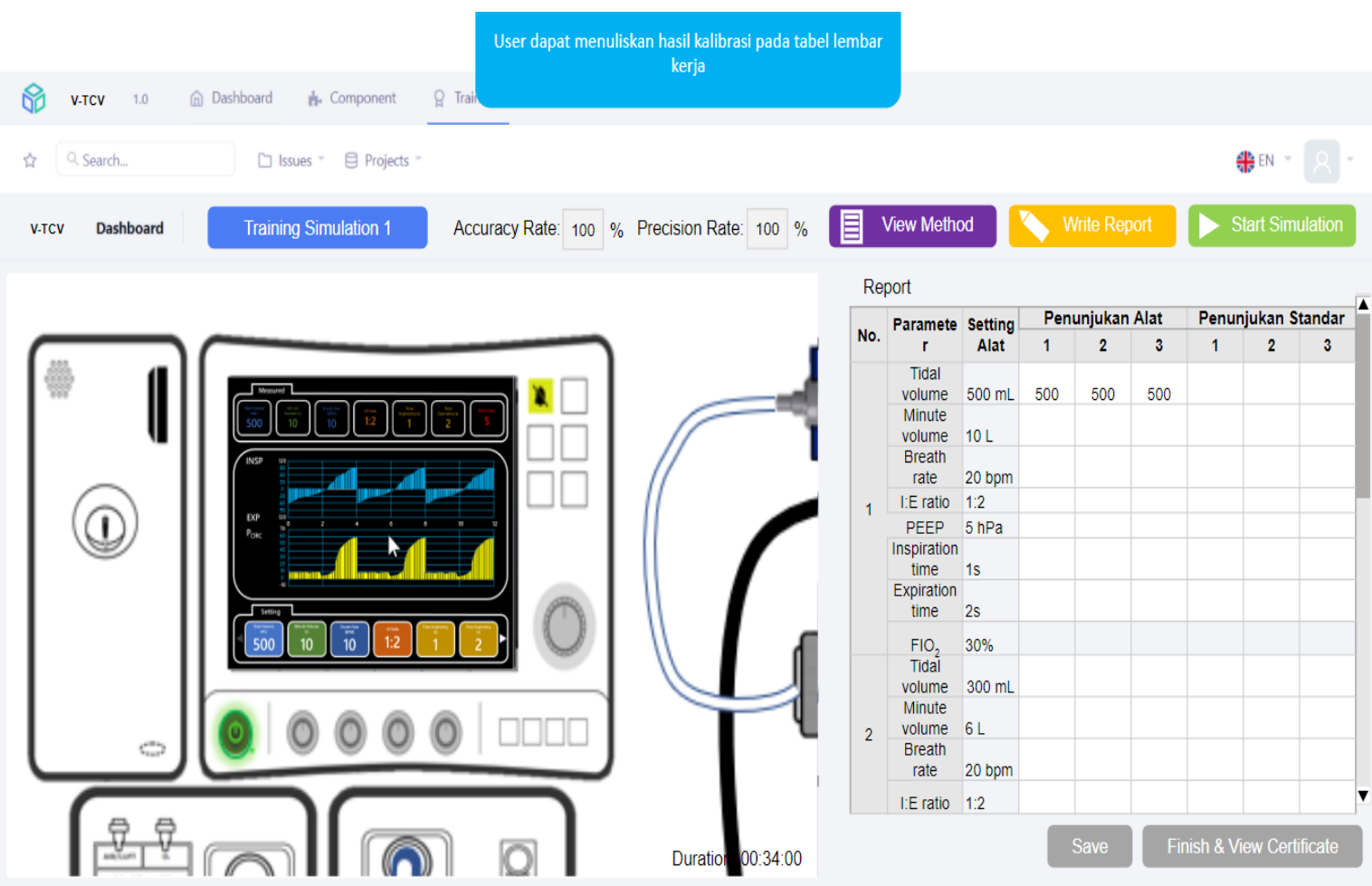

Gambar 6. Pengisian Lembar Kerja

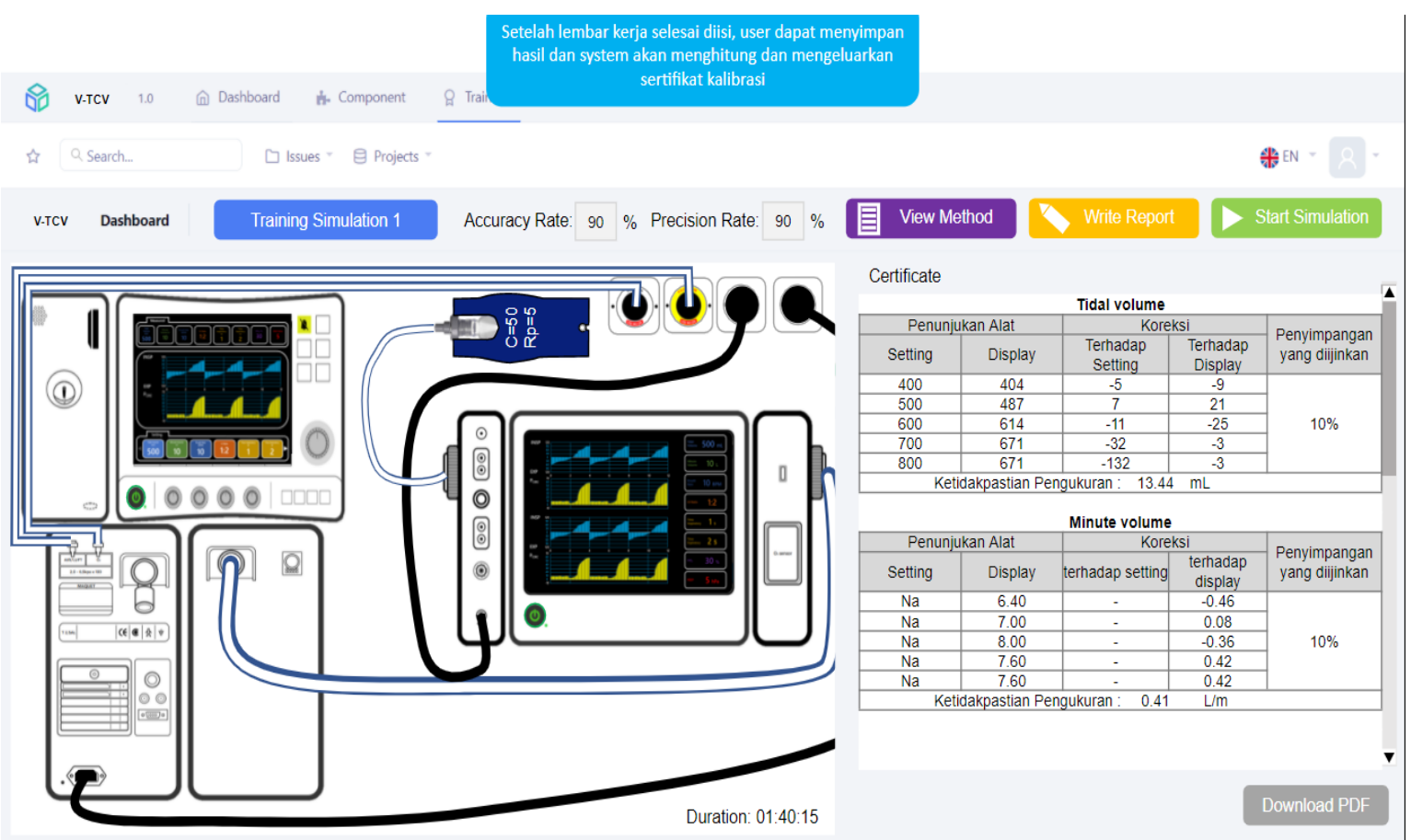

Gambar 7. Pembuatan Sertifikat Kalibrasi 


\section{Hasil Pengujian Fungsi dan Pengalaman Pengguna}

Hasil pengujian fungsi platform dapat dilihat pada Tabel 1.Dapat dilihat bahwa seluruh fitur yang direncanakan berhasil dilakukan pada platform.

Tabel 1. Hasil Pengujian Fungsi Platform

\begin{tabular}{|c|l|c|}
\hline No & \multicolumn{1}{|c|}{ Fitur } & $\begin{array}{c}\text { Hasil } \\
\text { Pengujian }\end{array}$ \\
\hline 1 & Registrasi & Berhasil \\
\hline 2 & Sign In & Berhasil \\
\hline 3 & Pembuatan Pelatihan (Generate Training) & Berhasil \\
\hline 4 & Peletakan Komponen pada Halaman Kerja & Berhasil \\
\hline 5 & Rotasi Komponen pada Halaman Kerja & Berhasil \\
\hline 6 & Menghubungkan Port antar komponen & Berhasil \\
\hline 7 & Circuit Error jika hubungan komponen belum sesuai & Berhasil \\
\hline 8 & Memulai simulasi & Berhasil \\
\hline 9 & Menghidupkan komponen & Berhasil \\
\hline 10 & Melakukan zoom-in zoom out pada halaman kerja & Berhasil \\
\hline 11 & $\begin{array}{l}\text { Mengatur selektor pada komponen sehingga pengaturan pada } \\
\text { monitor berubah }\end{array}$ & Berhasil \\
\hline 12 & Mengisi lembar kerja pengujian dan kalibrasi & Berhasil \\
\hline 13 & $\begin{array}{l}\text { Mengatur accuracy rate dan precision rate sehingga nilai terukur } \\
\text { memiliki perbedaan dengan nilai setting }\end{array}$ & Berhasil \\
\hline 14 & $\begin{array}{l}\text { Menyimpan data dan menampilkan sertifikat pengujian dan } \\
\text { kalibrasi }\end{array}$ & Berhasil \\
\hline
\end{tabular}

Hasil kuesioner pengalaman pengguna dapat dilihat pada Tabel 2.

Tabel 2. Hasil Kuesioner Pengalaman Pengguna Platform V-TCV

\begin{tabular}{|c|l|c|c|c|c|c|}
\hline No & \multicolumn{1}{|c|}{ Pertanyaan } & \multicolumn{4}{|c|}{ Jawaban } \\
\cline { 3 - 7 } & & $\begin{array}{l}\text { Sangat } \\
\text { tidak } \\
\text { setuju }\end{array}$ & $\begin{array}{c}\text { Tidak } \\
\text { setuju }\end{array}$ & Biasa & Setuju & $\begin{array}{c}\text { Sangat } \\
\text { setuju }\end{array}$ \\
\hline 1 & $\begin{array}{l}\text { Daya Tarik: Secara keseluruhan saya } \\
\text { menyukai produk ini }\end{array}$ & 1 & 1 & 3 & 11 & 4 \\
\hline 2 & $\begin{array}{l}\text { Efisiensi: Saya dapat menggunakan } \\
\text { platform ini dengan mudah }\end{array}$ & 1 & 0 & 5 & 7 & 7 \\
\hline 3 & $\begin{array}{l}\text { Perspicuity: Saya dapat mengenal } \\
\text { produk dan mudah mempelajari cara } \\
\text { penggunaannya }\end{array}$ & 1 & 2 & 5 & 5 & 7 \\
\hline 4 & $\begin{array}{l}\text { Ketergantungan: Saya dapat } \\
\text { mengendalikan interaksi }\end{array}$ & 1 & 1 & 5 & 7 & 6 \\
\hline 5 & $\begin{array}{l}\text { Stimulasi: Saya senang dan } \\
\text { termotivasi untuk menggunakan } \\
\text { produk }\end{array}$ & 1 & 1 & 3 & 7 & 8 \\
\hline 6 & $\begin{array}{l}\text { Novelty: Saya merasa produk inovatif } \\
\text { dan kreatif }\end{array}$ & 1 & 1 & 2 & 8 & 8 \\
\hline 7 & $\begin{array}{l}\text { Kepercayaan: Data yang saya } \\
\text { masukkan ke dalam produk ada di } \\
\text { tangan yang aman dan tidak } \\
\text { merugikan }\end{array}$ & 0 & 2 & 2 & 6 & 10 \\
\hline
\end{tabular}




\begin{tabular}{|c|l|c|c|c|c|c|}
\hline 8 & $\begin{array}{l}\text { Estetika: Produk terlihat bagus dan } \\
\text { menarik }\end{array}$ & 1 & 1 & 3 & 6 \\
\hline 9 & $\begin{array}{l}\text { Adaptabilitas: Produk dapat dengan } \\
\text { mudah disesuaikan dengan } \\
\text { preferensi atau gaya kerja saya }\end{array}$ & 1 & 1 & 3 & 7 & 8 \\
\hline 10 & $\begin{array}{l}\text { Kegunaan: Saya merasa produk } \\
\text { membawa keuntungan, menghemat } \\
\text { waktu atau dapat meningkatkan } \\
\text { produktivitas }\end{array}$ & 0 & 1 & 5 & 6 & 8 \\
\hline 11 & $\begin{array}{l}\text { Penggunaan Intuitif: Saya dapat } \\
\text { menggunakan produk langsung } \\
\text { tanpa pelatihan, instruksi, atau } \\
\text { bantuan dari orang lain. }\end{array}$ & 1 & 2 & 2 & 8 & 7 \\
\hline 12 & $\begin{array}{l}\text { Nilai: Produk berkualitas tinggi dan } \\
\text { dirancang secara profesional }\end{array}$ & 0 & 2 & 2 & 8 & 8 \\
\hline 13 & $\begin{array}{l}\text { Konten yang Dapat Dipercaya: } \\
\text { Informasi yang diberikan oleh } \\
\text { produk dapat diandalkan dan akurat }\end{array}$ & 1 & 1 & 3 & 8 & 7 \\
\hline 14 & $\begin{array}{l}\text { Kualitas Isi: informasi yang saya } \\
\text { dapat dari produk up to date, } \\
\text { dipersiapkan dengan baik dan } \\
\text { menarik }\end{array}$ & 1 & 1 & 3 & 7 & 8 \\
\hline 15 & $\begin{array}{l}\text { Haptics: Saya dapat merasa sensasi } \\
\text { menyentuh produk }\end{array}$ & 1 & 2 & 2 & 10 & 5 \\
\hline 16 & $\begin{array}{l}\text { Akustik: Platform ini tidak } \\
\text { mengeluarkan suara atau tidak bising } \\
\text { ketika digunakan }\end{array}$ & 1 & 1 & 1 & 9 & 8 \\
\hline
\end{tabular}

Dari hasil kuesioner pengalaman pengguna, sebagian besar pengguna setuju bahwa platform yang dikembangkan memiliki daya tarik. Hal ini dikarenakan platform yang dikembangkan memiliki inovasi desain yang kreatif dan mahasiswa maupun masyarakat dimanapun dan kapanpun dapat mengakses platform ini. Sebagian besar pengguna juga sangat setuju bahwa platform ini menjamin keamanan data pengguna. Hal ini dikarenakan telah diterapkannya sistem SSL pada website sehingga meminimalisir terjadinya hacking data terhadap platform. Data yang dihasilkan juga up to date dan bersifat satisfaction. Salah satu parameter yang disetujui oleh pengguna yaitu dapat merasakan sensasi menyentuh produk (Haptics). Dapat dianalisis bahwa platform simulasi virtual yang dikembangkan memiliki kesan seperti melakukan proses pengujian dan kalibrasi secara langsung dibandingkan hanya mempelajari teori saja ataupun menonton video.

\section{KESIMPULAN}

Kenapa platform dibuat dikarenakan ventilator berperan penting pada era COVID-19 pada pasien yang mengalami kelelahan atau kegagalan nafas sebagai alat bantu nafas. Berbagai institusi telah berusaha mengembangkan ventilator, akan tetapi banyak yang terkendala dengan hasil pengujian dan kalibrasinya yang tidak sesuai. Hal ini dikarenakan ketidaktahuan terhadap metode pengujian dan kalibrasi ventilator yang sesuai standar.

Dari penelitian ini, dikembangkanlah sebuah Platform Online Simulasi Virtual Pengujian dan Kalibrasi Ventilator Berbasis Browser yang memiliki tampilan interaktif yang terdiri dari model 2D ventilator dan alat uji dan kalibrasinya yaitu Electrical Safety Analyzer dan Gas Flow Analyzer beserta aksesoris yang dibutuhkan. Dan memiliki fitur pendaftaran startup, user (sign up), sing in, 
pembukaan jendela utama yang akan menampilkan toolbar, working area, elemen bar, peletakan elemen ke working area, pengaturan parameter elemen, pengkoneksian antar elemen, rubbing simulation, penampilan output, dll.

Berdasarkan hasil analisis dan pembahasan dapat diambil kesimpulan tentang pengalaman pengguna platform V-TCV sebagai berikut : berdasarkan persentase menunjukan platform yang disetujui karena platform berperan cukup penting dalam pengujian dan kalibrasi ventilator

Rekomendasi dalam pengembangan platform ini dalam pengefisienan platform yang mudah digunakan dan Perspicuity yang dapat mengenal produk dan mudah mempelajari cara penggunaannya.

\section{UCAPAN TERIMA KASIH}

Ucapan terima kasih disampaikan kepada Direktorat Jenderal Pendidikan Tinggi Kementerian Pendidikan dan Kebudayaan Republik Indonesia yang telah mendanai kegiatan ini dan juga kepada STIKes Al Insyirah Pekanbaru atas dukungannya.

\section{DAFTAR PUSTAKA}

Angel, E., 2017. The Case for Teaching Computer Graphics with WebGL: A 25-Year Perspective. IEEE Comput. Graph. Appl. 37, 106-112. https://doi.org/10.1109/MCG.2017.26

Angel, E., Shreiner, D., 2014. Interactive Computer Graphics with WebGL, 7th ed. AddisonWesley Professional.

Anwar, M.C., 2020. Membanggakan! Ini 5 Ventilator Corona Made in Indonesia. CNBC Indonesia. URL https://www.cnbcindonesia.com/tech/20200621121924-37166911/membanggakan-ini-5-ventilator-corona-made-in-indonesia (accessed 3.18.21).

Doolani, S., Wessels, C., Kanal, V., Sevastopoulos, C., Jaiswal, A., Nambiappan, H., Makedon, F., 2020. A Review of Extended Reality (XR) Technologies for Manufacturing Training. Technologies 8, 77. https://doi.org/10.3390/technologies8040077

Irwandy, 2020. Pertengahan Mei, Indonesia terancam krisis tempat tidur ICU, ventilator, dan APD karena kasus COVID-19 bisa melewati 50.000. The Conversation. URL http:/ / theconversation.com/ pertengahan-mei-indonesia-terancam-krisis-tempat-tidur-icuventilator-dan-apd-karena-kasus-covid-19-bisa-melewati-50-000-135442 (accessed 3.18.21).

Kementerian Kesehatan Republik Indonesia, 2018. Metode Kerja Pengujian dan atau Kalibrasi Alat Kesehatan.

Kolesnyk, M.Y., 2020. The First Experience Of Using The Body Interact Simulation Interactive Training Platform As A Part Of Interns Attestation.

Lee, A., Jang, I., 2019. Implementation of an open platform for 3D spatial information based on WebGL. ETRI J. 41, 277-288. https:/ / doi.org/10.4218/ etrij.2018-0352

LIPI, 2013. Laboratorium Teknologi Pengujian Peralatan Kesehatan [WWW Document]. P2SMTP LIPI. URL http:/ / smtp.lipi.go.id/berita39-Lab\%20Kesehatan.html (accessed 3.18.21).

Pears, M., Yiasemidou, M., Ismail, M.A., Veneziano, D., Biyani, C.S., 2020. Role of immersive technologies in healthcare education during the COVID-19 epidemic. Scott. Med. J. 65, 112-119. https:/ / doi.org/10.1177/0036933020956317

Ridge, G.D., Terzopoulos, D., 2019. An Online Collaborative Ecosystem for Educational Computer Graphics, in: The 24th International Conference on 3D Web Technology, Web3D '19. 
Association for Computing Machinery, New York, NY, USA, pp. 1-10. https:/ / doi.org/10.1145/3329714.3338133. 